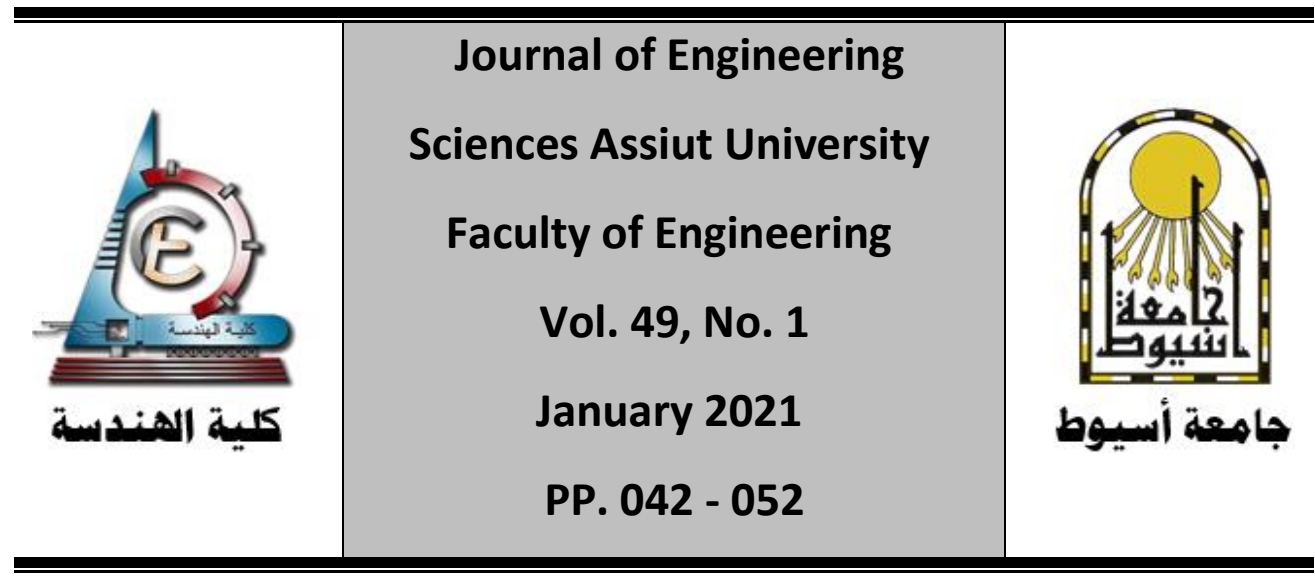

\title{
OPTIMIZATION OF ELECTROLESS NI-P COATING BATH AND ITS IMPACT IN THE INDUSTRIAL APPLICATIONS
}

\author{
Refaie Omar ${ }^{1}$, Mohmoud A. El-Sharief ${ }^{2}$
}

${ }^{1}$ Assist. Professor of Department of Mining and Metallurgical Engineering, Assiut University, Assiut, Egypt.Email: dr refaie@aun.edu.eg

${ }^{2}$ Assoc. Professor of Department of Mechanical Engineering, Assiut University, Assiut, Egypt.Email: msharif@aun.edu.eg

Received 30November 2020; Revised 31 December 2020; Accepted 6 January 2021

\begin{abstract}
:
Electroless Ni-P coating is widely used in industrial engineering applications due to its ability to alter and improve the surface properties of the steel substrates. Electroless nickel coating introduce an excellent combination of surface properties, where, it could add brightness, luster, and good appeal. The final coating layer also possess a very good adhesion with the coated substrates, this is the reasons for using such layer as an 'undercoat' for other coatings. The ability to produce a very homogenous composition and produce coating with a high corrosion resistance are mainly based on the plating bath composition. The present work investigates the influence of bath compositions, which included nickel sulphate, sodium hypophosphite and trisodium citrate, on the process of electroless $\mathrm{Ni}-\mathrm{P}$ coating. The deposition rate (Dr) as well as the bath stability were monitored to optimize the plating bath conditions with the different composition. The results of this work showed that
\end{abstract}


the deposition rate of coating layer increase with the increase of nickel source and reducing agent while; sodium citrate concentration in the plating bath has adverse effect on the deposition rate of coating.

Keywords: Ni-P electroless plating, reducing agent, complex agent, bath stability.

\section{Introduction}

Brenner and Riddell introduced the electroless coating technique for first time in 1945 [1]. The method was new as they do not require any external electricity. Since then and until today, it has evolved into a mature subject of research and development due to its wide range of applications [2] . The old processes were used to deposit the metallic coating without external current usually involve immersion plating or homogenous chemical reduction process (silvering) [3]. In immersion plating process, the base material is dissolved into the solution; meanwhile, the metallic ions in the solution are reduced on the surface of the base material. Such processes did not accepted for practical applications, as their result coating has weak adherence and poor properties [3]. Electroless nickel coating technique reactions involves nickel ions reduction and film deposition result from oxidation of a reducing agent present in the plating bath, which provides an internal electrons needed for coating [2,3]. Electroless Nickel-Phosphorus (NiP) coatings have been used increasingly in various industries since the early 1980's. Some of the outstanding characteristics of these coatings are superior corrosion and wear resistance, excellent uniformity, wide range of thickness as well as good mechanical and physical properties, good solderability, and surface lubricity [2-7] . In addition, compared to conventional electroplating methods, electroless nickel coatings can be applied on different substrates (conductive and nonconductive) since no external current is applied to the component [8]. Electroless nickel plating produces an amorphous deposit in the as-plated condition. Since the deposit is not dependent on current distribution, it is almost uniform in thickness, regardless of the size or shape of the plated surface $[7,9$, 10]. Table 1 shows the main components of electroless plating and function of each component $[3,4,7]$. 
Refaie Omar and Mohmoud A. El-Sharief, Optimization of Electroless Ni-P Coating Bath....

Table 1 Components and parameters of bath and their functions.

\begin{tabular}{|c|l|}
\hline Component & \multicolumn{1}{|c|}{ Function } \\
\hline Source of metal & Metal ions source \\
\hline Reducing agent & Supplying electrons to reduce the metal ions \\
\hline Complexing agent & To control the free nickel available to the reaction \\
\hline Accelerators & $\begin{array}{l}\text { Accelerate the reducing agent and increase the } \\
\text { deposition }\end{array}$ \\
\hline Stabilizers & Stabilizing the bath from decomposition \\
\hline Buffers & Sustaining the pH for long time \\
\hline pH regulators & adjusting the pH value \\
\hline Temperature & Energy for deposition \\
\hline
\end{tabular}

The current study will focus on optimization of bath composition for the electroless Ni-P coating including nickel source, reducing agent, and the complexing agent.

\section{Experimental Work}

\subsection{Specimens Preparation}

Steel specimens (1030 steel) were used for the electroless Ni-P plating experiments. The specimens shape was disk with two flat surfaces (12 $\mathrm{mm}$ in diameter and $6 \mathrm{~mm}$ height).

The specimen flat surface was polished up to 1200 grit with silicon carbide papers, followed by 3 and $1 \mu \mathrm{m}$ diamond-paste polishing respectivley. Specimens surfaces were then cleaned in ethanol ultrasonic bath for 10 minutes followed by degreasing in $10 \% \mathrm{NaOH}$ solution for another 10 minutes at $60{ }^{\circ} \mathrm{C}$. The final ultrasonic cleaning was applied on the sample for another 10 minutes in ethanol. Specimens washed with deionized water after each step. The weight of the substrate before coating (w1) determined and its surface was activated into a hydrochloric acid $(40 \mathrm{vol} \% \mathrm{HCl})$ for 30 seconds and specimen delivered to the coating bath.

\subsection{Samples coating}

All chemicals used were analytical reagents $(A R)$ and purchased from Sigma-Aldrich and deionized water $(>17 \mathrm{M} \Omega . \mathrm{cm})$ were used. The 
plating cell was consisted of a $200 \mathrm{ml}$ double wall beaker heated by digitally controlled circulated water baths feed. Magnetic stirrer with 300 rpm with a $P T F E$ coated magnetic rod $(3 \mathrm{~cm})$ was used.

After plating at $80 \pm 1^{\circ} \mathrm{C}$ for $1 \mathrm{hr}$, the specimen washed in DI water and ethanol respectively dried with nitrogen gas and w2 was then determined, and the deposition rate $(D r)$ calculated by weight gain method according to equation (1) [11].

$$
\text { Deposition rate }(D r)=\frac{w 2-w 1}{\rho \times A \times t} \quad \mu \mathrm{m} \mathrm{h}^{-1}
$$

Where: ' $\rho$ ' is the density of nickel, ' $A$ ' is the surface area of the specimen and ' $t$ ' is the coating time.

\section{Results and discussion}

The electroless Ni-P solution consists mainly of a source of nickel ions, a reducing agent, and a complexing agent. This study aims to investigate the three main components of bath and optimize them according to the deposition rate and the stability of the solution with using tri-sodium citrate as a complexing agent. Sodium citrate is one of the most common complexing agents used in electroless nickel coating [11-15]. The reason for such wide usage is due to its high stability to limit reaction with the substrate surface and to inhibit the decomposition of bath solutions [16]. In the current study, for nickel ions source nickel sulfate was used, sodium citrate was used as a complexing agent and sodium hypophosphite as a reducing agent. To minimize the total number of trials, experiments arrangement as well as the results were designed and fitted to $L 9$ orthogonal array (Taguchi analysis). Each component concentrations and samples arrangement, as well as the operating conditions, are summarised in Table 2. 
Table 2 Arrangement of samples and operating conditions

\begin{tabular}{|c|c|c|c|c|c|}
\hline 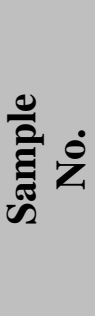 & 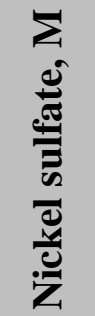 & 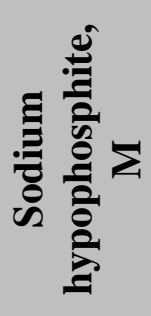 & 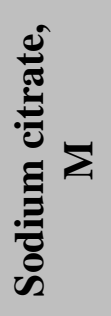 & 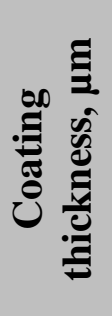 & 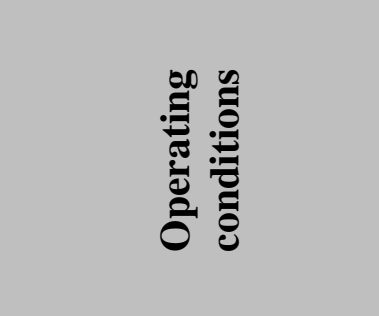 \\
\hline S1 & 0.05 & 0.15 & 0.05 & 3.3 & \multirow{9}{*}{$\begin{array}{ll}- & \mathrm{pH} 4.7 \pm 0.15 \\
- & 1 \mathrm{mg} \mathrm{L}{ }^{-1} \text { thiourea } \\
- & \text { Temperature } \\
& 80 \pm 1^{\circ} \mathrm{C} \\
- & \text { Bath Volume } 200 \\
& \text { ml } \\
- & \text { Stirrer Speed } 300 \\
& \text { rpm }\end{array}$} \\
\hline S2 & 0.05 & 0.25 & 0.10 & 0 & \\
\hline S3 & 0.05 & 0.35 & 0.15 & 0 & \\
\hline S4 & 0.10 & 0.15 & 0.10 & 3.8 & \\
\hline S5 & 0.10 & 0.25 & 0.15 & 1.3 & \\
\hline S6 & 0.10 & 0.35 & 0.05 & 12.8 & \\
\hline S7 & 0.15 & 0.15 & 0.15 & 3.7 & \\
\hline S8 & 0.15 & 0.25 & 0.05 & 13.1 & \\
\hline S9 & 0.15 & 0.35 & 0.10 & 15.1 & \\
\hline
\end{tabular}

\subsection{Effect of bath composition on the deposition rate (Dr):}

The deposition rate for each bath composition was calculated and plotted by Minitab program according to Taguchi orthogonal array L9 for design of the experiment [17-20], as shown in Fig.1., It is noticeable that, the increase of nickel sulphate and sodium hypophosphite concentrations in the plating bath, increase the deposition rate.

Nickel sulfate is the source of nickel ions to be plated and sodium hypophosphite is the reducing agent that introduces the electrons required for deposition process according to the electrochemical mechanism (equations 1 to 3 ). This mechanism considered that $\mathrm{Ni}$ plating is resulted from anodic and cathodic reactions. The anodic reaction is the oxidation of hypophosphite with water, which generates electrons needed for cathodic reactions according to the equation $1[4,5$, 21-23]:

$\mathrm{H}_{2} \mathrm{PO}_{2}^{-}+\mathrm{H}_{2} \mathrm{O} \rightarrow \mathrm{H}_{2} \mathrm{PO}_{3}^{-}+2 \mathrm{H}+2 \mathrm{e}^{-} \quad \mathrm{E}^{\circ}=0.50 \mathrm{~V}$.

Cathodic reaction:

$\mathrm{Ni}^{++}+2 \mathrm{e} \rightarrow 2 \mathrm{Ni}$

$$
\begin{aligned}
& \mathrm{E}^{\circ}=-0.25 \mathrm{~V} . \\
& \mathrm{E}^{\circ}=-0.50 \mathrm{~V} .
\end{aligned}
$$$$
\mathrm{H}_{2} \mathrm{PO}_{2}^{-}+2 \mathrm{H}^{+}+2 \mathrm{e} \rightarrow \mathrm{P}+2 \mathrm{H}_{2} \mathrm{O}
$$ 


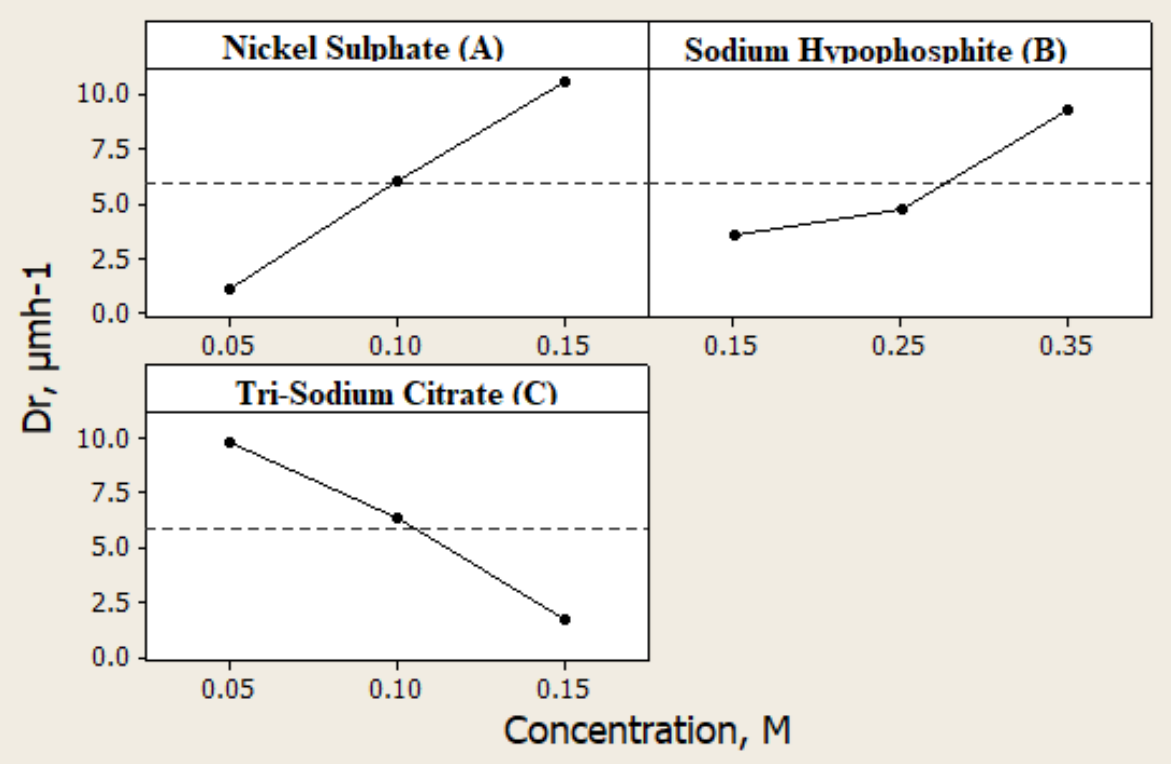

Figure 1 Effect of bath composition on the deposition rate (Dr)

The concentration of sodium citrate shows a negative effect on the deposition rate, as the citrate concentration increases in the bath, the complexed nickel ions increase, and the remained nickel ions used in plating decrease (equation 4). When a coordination site of a metal ion is complexed, that site is not as reactive since it is no longer coordinated with a weakly bound water molecule. Since the electroless plating reaction only takes place at vacant or 'free' coordination sites, the concentration of complexing agents in the plating bath is very important to control these vacant sites as follows [16]; When a complexing agent $(\mathrm{L})$ is in solution, the free $\left(\mathrm{M}^{+\mathrm{z}}\right)$ and complexed $\left(\mathrm{ML}_{\mathrm{m}}{ }^{(\mathrm{z}-\mathrm{mn})}\right)$ sites reach a state of equilibrium according to the following:

$\mathrm{M}^{+\mathrm{z}}+\mathrm{mL}^{-\mathrm{n}} \leftrightarrow \mathrm{MLm}^{(\mathrm{z}-\mathrm{nm})}$

Where $\mathrm{MLm}^{(\mathrm{z}-\mathrm{nm})}$ denotes the metal complex, $\mathrm{M}^{+\mathrm{z}}$ the free metal ions and $\mathrm{L}^{-\mathrm{n}}$ the free complex [24]. The calculated deposition rate was tested and confirmed by SEM imaging for a coated sample with a maximum coating thickness of $15 \mu \mathrm{m}$ as shown in Fig 2. The SEM cross-section image confirms the thickness calculation with a reasonable error. 


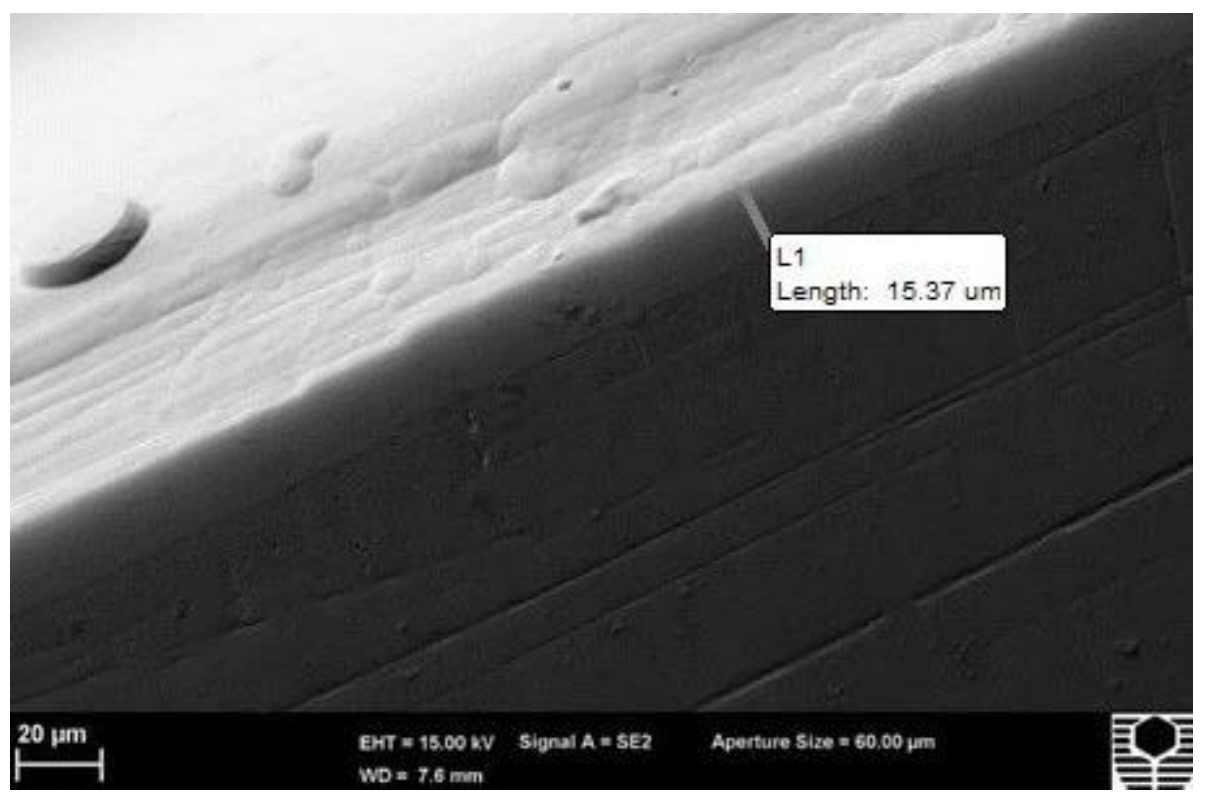

Figure 2 SEM cross-section image of the maximum coating thickness (S1).

\subsection{Effect of bath composition on the buffering capacity $(\Delta \mathrm{pH} / \mathrm{g})$}

It is well known that, for $\mathrm{Ni}$ deposition, the $\mathrm{H}^{+}$are generated according to the atomic hydrogen mechanism. The atomic hydrogen is produced from hypophosphite reduction with water, and is then desorbed at the catalytic surface according to the equations below [23]:

$\mathrm{H}_{2} \mathrm{PO}_{2}^{-}+\mathrm{H}_{2} \mathrm{O} \rightarrow \mathrm{H}_{2} \mathrm{PO}_{3}^{-}+2 \mathrm{H}_{\text {ads }}$

At the catalytic surface, the adsorbed hydrogen reduces $\mathrm{Ni}^{2+}$ according to the reaction:

$2 \mathrm{H}_{\mathrm{ads}}+\mathrm{Ni}^{++} \rightarrow \mathrm{Ni}+2 \mathrm{H}^{+}$

Finally, atomic hydrogen combines and evolves as a hydrogen bubble. The accumulation of hydrogen ions $\left(\mathrm{H}^{+}\right)$in the plating bath lowers the $\mathrm{pH}$ of the solution. It is well known that when the $\mathrm{pH}$ decreases, the rate of electroless coating deposition decreases [22, 25-28]. The amount that the $\mathrm{pH}$ changes as a result of the formation of $\mathrm{H}^{+}$is related to the buffer capacity of the solution components [16]. Fig. 3 shows the effect of each bath component on the buffering capacity of the plating solution. 


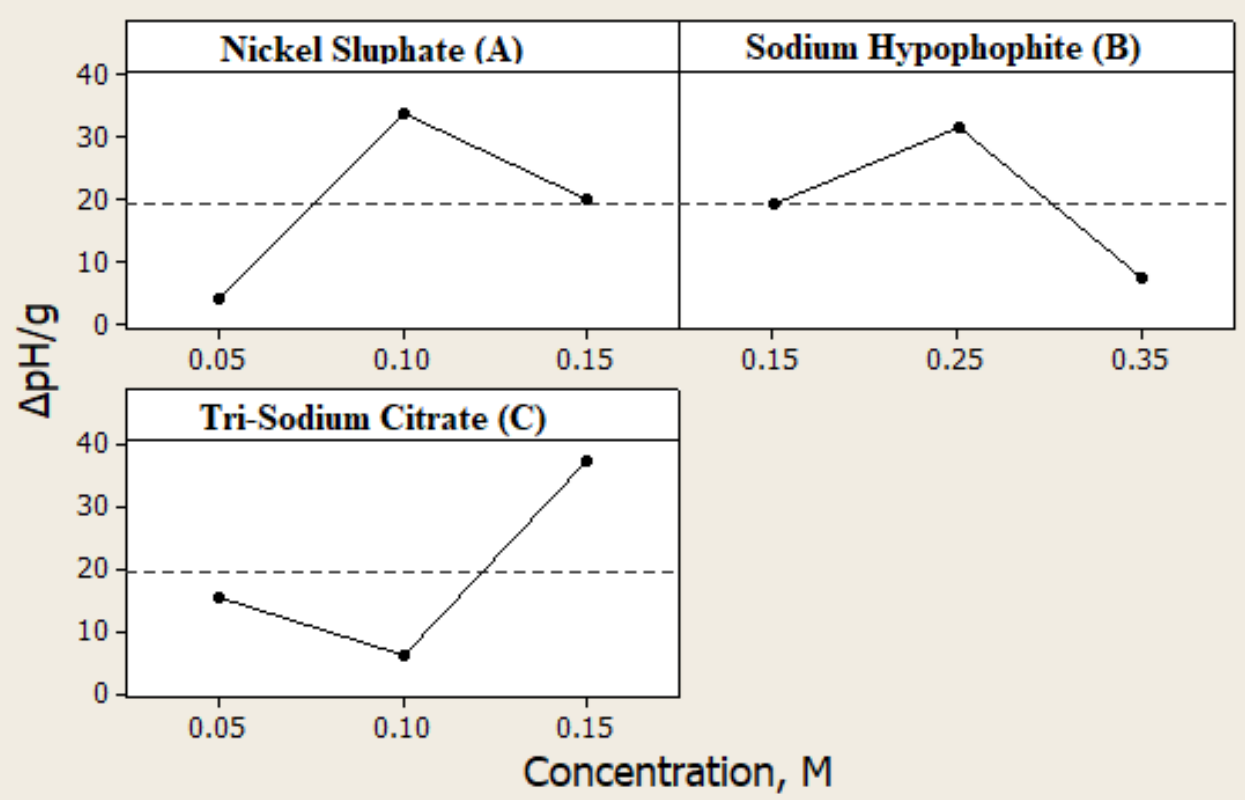

Figure 3 Effect of bath composition on the bath stability $(\Delta \mathrm{pH} / \mathrm{g})$

From Fig 3, it can be remark that the plating bath becomes more stable and the bath buffering has been improved (smaller variation in solution $\mathrm{pH}$ ) at concentration of $0.5 \mathrm{M}$ for tri-sodium citrate.

\section{Conclusions and Recommendations}

The investigating results include the deposition rate as well as the stability of the coating bath. The results can be concluded as follow:

- The electroless Ni-P coating deposition rate can be maximized by controlling the coating bath composition.

- The increase of nickel source and reducing agent increases the deposition rate remarkably while; sodium citrate concentration in the plating bath decreases the deposition rate of coating.

- The bath stability should be taken in consideration during applications in industrial scale as it indicates the bath life and ability to reused for many times.

- Bath stability can be maximized with sodium citrate with concentration of $0.1 \mathrm{M}$ in the coating bath. 


\section{References}

[1] Abner, B. and G.E. Riddell, Nickel plating by chemical reduction. 1950, Google Patents.

[2] Sahoo, P. and S.K. Das, Tribology of electroless nickel coatings-a review. Materials \& Design, 2011. 32(4): p. 1760-1775.

[3] Sudagar, J., J. Lian, and W. Sha, Electroless nickel, alloy, composite, and nano coatings - A critical review. Journal of Alloys and Compounds, 2013. 571: p. 183-204.

[4] Agarwala, R. and V. Agarwala, Electroless alloy/composite coatings: A review. Sadhana, 2003. 28(3-4): p. 475-493.

[5] Krishnan, K.H., S. John, K. Srinivasan, J. Praveen, M. Ganesan, and P. Kavimani, An overall aspect of electroless Ni-P depositions - a review article. Metallurgical and Materials Transactions A, 2006. 37(6): p. 1917-1926.

[6] Kundu, S., S.K. Das, and P. Sahoo, Properties of Electroless Nickel at Elevated Temperature-a Review. Procedia Engineering, 2014. 97: p. 1698-1706.

[7] Loto, C.A., Electroless Nickel Plating - A Review. Silicon, 2016. 8(2): p. $177-$ 186.

[8] Taheri, R., Evaluation of electroless nickel-phosphorus (EN) coatings. Saskatoon: University of Saskatchewan Saskatoon, 2002.

[9] Schlesinger, M., and M. Paunovic, Modern electroplating. Vol. 55. 2011: John Wiley \& Sons.

[10] Osifuye, C., A. Popoola, C. Loto, and D. Oloruntoba, Effect of bath parameters on electroless Ni-P and Zn-P deposition on 1045 steel substrate. Int J Electrochem Sci, 2014. 9: p. 6074-6087.

[11] Karthikeyan, S. and B. Ramamoorthy, Effect of reducing agent and nano Al2O3 particles on the properties of electroless Ni-P coating. Applied Surface Science, 2014. 307: p. 654-660.

[12] Gadhari, P. and P. Sahoo, Effect of Process Parameters on Microhardness of NiP-Al2O3 Composite Coatings. Procedia Materials Science, 2014. 6: p. 623-632.

[13] Sharma, A. and A.K. Singh, Electroless Ni-P-PTFE-Al2O3 Dispersion Nanocomposite Coating for Corrosion and Wear Resistance. Journal of Materials Engineering and Performance, 2013. 23(1): p. 142-151.

[14] Gadhari, P. and P. Sahoo, Influence of Process Parameters on Multiple Roughness Characteristics of Ni-P-TiO2 Composite Coatings. Procedia Engineering, 2014. 97: p. 439-448.

[15] Ahmadi Ashtiani, A., S. Faraji, S. Amjad Iranagh, and A.H. Faraji, The study of electroless Ni-P alloys with different complexing agents on $\mathrm{Ck} 45$ steel substrate. Arabian Journal of Chemistry, 2017. 10: p. S1541-S1545.

[16] Mallory, G.O. and J.B. Hajdu, Electroless plating: fundamentals and applications. 1st ed. 1990, New York (US): William Andrew.

[17] Pandaa, A.K. and R. Singhb, Optimization of Process Parameters by Taguchi Method: Catalytic degradation of polypropylene to liquid fuel. Int. J. of Multidisciplinary and Current research, 2013: p. 50-54.

[18] Muraliraja, R., R. Elansezhian, and K. Patterson, Optimization of Reducing Agent and Key Parameters Effect on the Efficiency of Electroless Ni-P Plating by Taguchi Method. Procedia Materials Science, 2014. 5: p. 2478-2486. 
[19] Park, I.-C. and S.-J. Kim, Cavitation erosion behavior in seawater of electroless Ni-P coating and process optimization using Taguchi method. Applied Surface Science, 2018.

[20] Omar, R., M. Aboraia, and E. Oraby, Optimization of the electroless Ni-P coating in glycine bath by Taguchi method. Journal of Engineering Sciences, Assiut University, 2019. 47(1): p. 40-48.

[21] Yaghoobi, M., B. Bostani, P. Asl farshbaf, and N.P. Ahmadi, An investigation on Preparation and Effects of Post Heat Treatment on Electroless Nanocrystalline Ni-Sn-P Coatings. Transactions of the Indian Institute of Metals, 2017. 71(2): p. 393-402.

[22] Beygi, H., H. Vafaeenezhad, and S.A. Sajjadi, Modeling the electroless nickel deposition on aluminum nanoparticles. Applied Surface Science, 2012. 258(19): p. 7744-7750.

[23] Stankiewicz, A., I. Szczygieł, and B. Szczygieł, Summary of Existing Models of the Ni-P Coating Electroless Deposition Process. International Journal of Chemical Kinetics, 2013. 45(11): p. 755-762.

[24] Huang, Y.S. and F.Z. Cui, Effect of complexing agent on the morphology and microstructure of electroless deposited Ni-P alloy. Surface and Coatings Technology, 2007. 201(9-11): p. 5416-5418.

[25] Anik, T., M.E. Touhami, K. Himm, S. Schireen, R. Belkhmima, M. Abouchane, and $\mathrm{M}$. Cissé, Influence of $\mathrm{pH}$ solution on electroless copper plating using sodium hypophosphite as reducing agent. Int. J. Electrochem. Sci, 2012. 7(3): p. 2009-2018.

[26] 26. Szczygieł, B. and A. Turkiewicz, Aminoacetic acid as complexing agent in baths for electroless deposition of Ni-W-P coatings. Transactions of the IMF, 2006. 84(6): p. 309-312.

[27] Gawad, S.A., A. Baraka, M. Morsi, and M.A. Eltoum, Development of Electroless Ni-P-Al2O3 and Ni-P-TiO2 Composite Coatings from Alkaline Hypophosphite Gluconate Baths and their Properties. International Journal of Electrochemical Science, 2013. 8: p. 1722-1734.

[28] Chen, L., D. Zeng, Z. Liu, S. Bai, and J. Li, Improving the Fatigue Crack Propagation Resistance and Damage Tolerance of 2524-T3 Alloy with Amorphous Electroless Ni-P Coating. Journal of Materials Engineering and Performance, 2018. 27(2): p. 881-888. 
Refaie Omar and Mohmoud A. El-Sharief, Optimization of Electroless Ni-P Coating Bath....

$$
\text { الظروف المثالية لمحلول الطلاء اللاكهربي بالنيكل ومردوده في التباتي }
$$

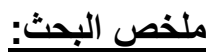

يستخدم الطلاء اللاكهربي بالنيكل على نطاق واسع في الكثير من الصناعيات الهندسة نظرًا لقدرته على تغيير وتحسين خصائص أسطح المشغولات المصنوعة من الصلب وسبائكه. إذ يقام هذا النوع من الطلاء مزيجًا ممتازًا من خصائص الاسطح للمنتجات المطلية ويمكن أن يضيف السطوع و اللمعان وكذلك المظهر الجيد للسطح النهائي. تتميز طبقة الطلاء النهائية أيضًا بالالتصاق الجيد جدًا مع الاسطح المطلية، ولهذا فكثيرا ما يستخدم الطلاء اللاكهربي بالنيكل كطبقة طلاء أولى لأنواع أخرى من الطلاءات. انتاج طبقة طلاء متجانسة التركيب لها مقاومة عالية للتآكل يعتمد بشكل أساسي على تركيبة محلول الطلاء المستخدم. لذلك يدرس هذا البحث تأثير تركيبات محلول الطلاء المختلفة، و التي تتضمن كبريتات النيكل و هيبوفوسفيت الصوديوم وسترات الصوديوم، على جودة طبقة الطلاء بالنيكل. وقد استخدم كلا من معدل الترسيب للطلاء (Dr) وكذلك ثبات حامضية محلول الطلاء لمقارنة وضبط مثالية المتغيرات للعملية مع التركيزات المختلفة لمكونات محلول الطلاء. أظهرت نتائج هذا العمل أن معدل ترسيب طبقة الطلاء يزداد مع زيادة مصدر النيكل والعامل المختزل بينما تركيز سترات الصوديوم في محلول الطلاء لله تأثير سلبي على معدل الترسب. 